\title{
Fear of COVID-19: A cross-sectional study among general population in Telangana during lockdown
}

\author{
Shadma Siddiquie ${ }^{1}$, Mazher Ali ${ }^{2}$, Khan Mohammed Zeeshan Ali $^{3^{*}}$, Khaja Shakeeb Ahmed Atif ${ }^{4}$, Minhaj Zafar \\ Nasirabadi $^{5}$
}

${ }^{1,4}$ Post graduate Resident, ${ }^{2,3}$ Senior Resident, ${ }^{5}$ Professor and HOD, Dept. of Psychiatry, Deccan College of Medical Sciences, Hyderabad, Telangana, India

\section{*Corresponding Author: Khan Mohammed Zeeshan Ali}

Email: drmzak49@gmail.com

\begin{abstract}
Background: The Novel Coronavirus-19, emerged from Wuhan, China, spread throughout the world. This pandemic with its influence on each and every aspect of life, posed a much greater impact on mental health. Heightened level of anxiety, fear of contracting the virus, future uncertainties are commonly seen among general population during pandemics.

Aim: To assess the fear of COVID-19 among general population of Telangana during lockdown period in India.

Materials and Methods: An online survey was conducted using Google Forms. Fear of Covid-19 scale was used for assessment. Non probability snow ball sampling technique was used for collecting data.

Results: A total of 245 responses were received, of which 10 responders had pre-existing psychiatric illness and were excluded. Of the remaining 235 participants, $47.2 \%$ were females and 52.8\% were males. Mean age was $31.46 \pm 9.82$ years. 54\% were educated till postgraduate level. $51.1 \%$ were married. $32 \%$ were health care professionals and involved in essential care services. The mean score of Fear of Covid-19 scale was $14.27 \pm 4.29$. 74.9\% participants had fear of Covid-19. 61.7\% felt uncomfortable when thinking about the novel Corona virus. More than 39.6\% candidates were distressed on hearing/watching news about Covid-19. Around 13\% participants reported disturbance in their sleep due to worry of getting infected with Corona virus. Findings imply that there was fear of Covid-19 spread among general population of Telangana during lockdown period.
\end{abstract}

Keywords: COVID-19, Fear, Lockdown, Pandemic, Telangana.

\section{Introduction}

The novel corona virus probably started its spread in December 2019, from a sea food market in Wuhan China. ${ }^{1,2}$

WHO declared it as a 'Public Health Emergency of International Concern' on $30^{\text {th }}$ January 2020 due to its rapid spread across the globe. ${ }^{2}$ The state of lockdown was applied to many parts of world. On $24^{\text {th }}$ March 2020, Government of India ordered a nationwide lockdown for 21days, limiting movement of the entire 1.3 billion population, as a preventive measure against the spread of the virus. ${ }^{3}$ The COVID-19 virus pandemic and the resulting lockdown globally, has had a severe impact on multiple facets of day to day life, functioning and mental health. ${ }^{2}$

According to Ministry of Health \& Family Welfare (MoHFW), hearing about COVID-19 from various sources can give rise to fear, anxiety, panic. ${ }^{4}$

The emergence of COVID $19^{5}$ and its pandemic nature has exacerbated fears worldwide. The affected individuals also experienced stigma, in the form of discriminations, labelling, stereotyping and negative behaviours. ${ }^{6}$

On $18^{\text {th }}$ March 2020 WHO has emphasised concerns relating to mental health issues, to reduce stigmatisation arising during COVID 19. ${ }^{2,7}$ According to a survey done among 130 countries by WHO, Corona virus pandemic has disrupted mental health services in $93 \%$ of countries worldwide, while demand for mental health is increasing. ${ }^{8}$

This study was done to assess the fear of Covid-19 among general population of Telangana, and was conducted during first phase of lockdown period, to increase awareness.

\section{Materials and Methods}

The study was a cross sectional, observational study. Non probability snow ball sampling technique was used. An online questionnaire consisting of socio-demographic details and Fear of Covid-19 scale, was developed using Google forms.

\section{Inclusion criteria}

Persons $\geq 18$ years of age and those who could understand English.

\section{Exclusion criteria}

Participants with a history of psychiatric illness.

The study was started after obtaining approval from the Institutional Ethics Committee. Data collection was initiated from $15^{\text {th }}$ April 2020, during first phase lockdown period in India, Online forms were available for a period of 30 days. Data collection was concluded after the allotted time period of 30 days.

The questionnaire was divided into two sections, with a consent form attached. The link of the questionnaire was circulated through sms, e-mail, WhatsApp and other social media applications. The participants were encouraged to roll out the survey to as many contacts as possible. After clicking on the link, the participants were directed to a page describing the study, and assuring them of the confidentiality of the data, along with the attached consent form.

After taking an informed consent, a set of questions would appear, which the participants had to answer. 
Provisions were made to ensure only one response per question.

First section consisted of sociodemographic variables like age, gender, qualification, occupation, involvement in essential services. It also included medical history and history of pre-existing psychiatric illness. Responses of those with pre-existing psychiatric illness were excluded from the study, before analysis. Fear of Covid -19 scale (FCV-19), was used in the second section. It is a seven item scale and is a reliable and valid tool for assessing fear of Covid-19 among general population. It has an Internal consistency $[\alpha=0.82]$ and test retest reliability $[\mathrm{ICC}=0.72]{ }^{9}$ Though the scale was created by Iranian researchers, the authors felt that the questions were generic/non specific and could be applied to other populations as well.

At the end of questionnaire, candidates were requested to click on Submit option, for proper submission of their form.

All the questions were in multiple choice format, and the responses were rated on a 5 point Likert scale.

Data was entered in Microsoft excel and analysis was done using SPSS version 20. Descriptive statistical analysis was done. Results on continuous measurements are presented as Mean and Standard Deviation

Results on categorical measurements are presented as Percentages.

Significance is assessed at 5\% level of significance ( $p<$ 0.05 - statistically significant).

Student t test (independent, two tailed) has been used to find out the significance of study parameters on a continuous scale between two gender groups.

Analysis of Variance (ANOVA) has been used to find out the significance of study parameters on a continuous scale between three and more age groups.

\section{Results}

An online survey, related to fear of Covid-19, was conducted among general population of Telangana during lockdown period in India.

\section{Socio-demographic details}

Total of 245 responses were received, from various parts of Telangana. 10 participants had pre-existing psychiatric illness, and were excluded. Thus, result was analysed for a total of 235 participants. The youngest participant was 18 years old and eldest was 79 years old. Mean age was 31.46 \pm 9.82 years. (Table 1 )

The gender ratio of respondents was almost equal (Males were 52.8\%, Females were 47.2\% (Fig. 1, Table 2). $51.1 \%$ of participants were married (Fig. 2, Table 2).

Minimum qualification was Class $12^{\text {th }}$ and the maximum was post graduation. $40 \%$ of the participants were graduates and $54 \%$ were Post graduates. (Table 2)

$31 \%$ of the participants were health care professionals and involved in Frontline services. (Table 2)

$51.5 \%$ and $17.4 \%$ participants were residing in nuclear and joint families respectively (Fig. 3, Table 2).

II) Fear of Covid 19 scale (FCV-19):
FCV-19 scale, a seven item scale, has robust psychometric properties. ${ }^{9}$ It is a five item Likert type of scale, scores ranging from 5 to 35 . Higher the score, greater the fear of Covid-19. ${ }^{9}$

$74.9 \%$ of participants were afraid of COVID-19 (Fig. 4, Table 3), while $61.7 \%$ felt uncomfortable thinking about the novel Corona virus (Fig. 5, Table 3). 5\% of the candidates developed tremors or sweating in their hands when they thought about Corona virus. (Fig. 6, Table 3). 12\% of the participants reported increased autonomic activity (like palpitations) whenever they thought about getting infected with Covid-19. (Fig. 7, Table 3)

$39.6 \%$ candidates became nervous/anxious, restless on hearing about or watching news about COVID-19 on social media (Fig. 8, Table 3). 12.7\% participants complained about sleep disturbances (Fig 9, Table 3). 23.8\% were afraid of losing their life because of the disease. (Fig. 9, Table 3)

Overall mean score for this questionnaire was $14.27 \pm$ 4.29. The mean fear of COVID-19 (FCV-19) score in Males was $13.81 \pm 3.91$ (Table 4). Whereas, the mean FCV-19 score for Females was $14.78 \pm 4.65$ (Table 4, Graph 1). Student t test and ANNOVA were used to study the fear of COVID 19 between 2 or more than 2 groups respectively.

Using student-t test, it was ascertained that the mean fear of COVID-19 (FCV-19) score in Females (14.78 \pm 4.65) was not significant higher than that of males. (13.81 \pm 3.91), with p value 0.084 (Table 5).

For determining age wise distribution and fear of Covid-19 score, Analysis of Variance (ANOVA) was used. The mean FCV-19 score was highest in 71-80yr age group (79.00) and least in less than 20year age group (19.25 \pm 0.96). There is no statistical significance observed between age distribution and mean FCV-19 scores. $(\mathrm{p}=0.669)$ (Table 6)

\section{Discussion}

Fear is an emotion induced by perceived danger or threat, which causes physiological changes and ultimately behavioural changes. Though fear is a common psychological outcome during pandemics, the COVID-19 pandemic is a continuously evolving disease outbreak and has unique risk factors. ${ }^{10}$ Therefore, fear related to COVID19 might manifest in not only fear and anxiety related to disease contraction and dying, but also associated sociooccupational stress. This has had an impact on emotional wellbeing and mental state of individuals. ${ }^{13}$ The community has faced multiple challenges due to the Pandemic and the safety measures like lockdown. ${ }^{11-13}$ Experience from epidemics like SARS-CoV in 2003, MERS in 2012, Ebola in 2017 has shown us that these outbreaks can result in fear, anger, anxiety and loneliness. ${ }^{14}$ In the COVID-19 pandemic, as in other pandemics, ${ }^{16}$ fear, anxiety, depression, worries and post-traumatic stress disorders have been the major psychological consequences among general public, health care workers ${ }^{17}$ and survivors. ${ }^{15,18,20}$ COVID-19 related fear, mortality rates, unemployment, protective strategies have become the most searched topics in Google search history. ${ }^{10,19}$ 
COVID 19 had widespread impact on economy, mindset, day to day life of most individuals. ${ }^{20}$ Fear and anxiety related to epidemics and pandemics also influence the behaviour of people in the community. ${ }^{20}$

Researchers have used the expressions "fear of COVID-19"9 and corona phobia ${ }^{21}$ to indicate the fear of contracting COVID-19.

Corona phobia ${ }^{10,21}$ is defined as an excessive triggered response of fear of contracting the virus causing COVID-19, leading to accompanied excessive concern over physiological symptoms, significant stress about personal and occupational loss, increased reassurance and safety seeking behaviours, and avoidance of public places and situations, causing marked impairment in daily life functioning. ${ }^{10}$

Using Fear of Covid-19 scale (FCV-19S), we found out that, $74.9 \%$ (Fig. 4, Table 2) had fear of COVID 19 and more than 39\% (Fig. 8, Table 2) felt stressful on watching or hearing news of COVID 19 in any form of media. Thus, portraying the importance of media, and their impact over mental health of society.

Table 1: Mean age of participants

\begin{tabular}{|l|l|c|}
\hline Socio-Demographic Details \\
\hline S. No. & Items & \% of responses (N=235) \\
\hline 1 & Gender & $52.8 \%(\mathrm{~N}=124)$ \\
& Male & $47.2 \%(\mathrm{~N}=111)$ \\
\hline 2 & Female & $6 \%(\mathrm{~N}=14)$ \\
& Education & $40 \%(\mathrm{~N}=94)$ \\
& Intermediate & $54 \%(\mathrm{~N}=127)$ \\
\hline 3 & Graduation & \\
& Post- graduation & $31.6 \%(\mathrm{~N}=74)$ \\
& Occupation & $35 \%(\mathrm{~N}=82)$ \\
& Health care & $5 \%(\mathrm{~N}=13)$ \\
& Employee (private/government sector) & $10 \%(\mathrm{~N}=26)$ \\
& Business & $5 \%(\mathrm{~N}=10)$ \\
& Student & $13.4 \%(\mathrm{~N}=30)$ \\
\hline 4 & Homemaker & \\
& Others & $51.1 \%(\mathrm{~N}-120)$ \\
& Marital status & $47.2 \%(\mathrm{~N}=111)$ \\
& Married & $1.7 \%(\mathrm{~N}=4)$ \\
\hline
\end{tabular}

Table 2:

\begin{tabular}{|l|l|l|}
\hline Mean & N & Standard Deviation \\
\hline 31.46 & 235 & 9.82 \\
\hline
\end{tabular}

Table 3:

\begin{tabular}{|l|l|c|}
\hline Fear of Covid-19 scale (FCV-19) & $\begin{array}{c}\text { \% of responses who had fear } \\
\text { of Covid-19 (N=235) }\end{array}$ \\
\hline S. No. & Items & $74.9 \%$ \\
\hline 1 & Afraid of corona virus & $61.7 \%$ \\
\hline 2 & Uncomfortable to think about corona virus & \\
\hline 3 & $\begin{array}{l}\text { Tremors or sweating in hands when thinking about } \\
\text { corona }\end{array}$ & $11.5 \%$ \\
\hline 4 & $\begin{array}{l}\text { Palpitations when thinking about getting infected with } \\
\text { Corona }\end{array}$ & $39.6 \%$ \\
\hline 5 & $\begin{array}{l}\text { Nervous/anxious on watching news and stories about } \\
\text { corona virus }\end{array}$ & $12.7 \%$ \\
\hline 6 & Disturbance in sleep & $23.8 \%$ \\
\hline 7 & Afraid of losing life because of Corona & \\
\hline
\end{tabular}

Table 4: Mean FCV-19 score Gender wise distribution

\begin{tabular}{|l|c|c|}
\hline Gender & Frequency & Mean \\
\hline Males & 124 & $13.81 \pm 3.91$ \\
\hline Females & 111 & $14.78 \pm 4.65$ \\
\hline
\end{tabular}


Table 5: Gender co-relation and mean FCV-19 scores

\begin{tabular}{|l|c|c|c|}
\hline Parameter & Males & Females & P value \\
\hline Mean FCV-19 scores & $13.81 \pm 3.91$ & $14.78 \pm 4.65$ & 0.084 \\
\hline
\end{tabular}

(FCV-19: Fear of Covid-19)

Table 6: Age distribution and mean FCV-19 score

\begin{tabular}{|c|c|c|c|c|}
\hline Age distribution & $\mathbf{N}$ & Mean FCV-19 Score & Standard Deviation & P value \\
\hline$<20$ Years & 12 & 19.25 & 0.96 & \multirow{7}{*}{$0.669 \mathrm{NS}$} \\
\hline $21-30$ & 139 & 26.50 & 2.32 & \\
\hline $31-40$ & 45 & 33.73 & 2.75 & \\
\hline $41-50$ & 27 & 46.11 & 2.84 & \\
\hline $51-60$ & 8 & 55.75 & 3.10 & \\
\hline $61-70$ & 3 & 63.00 & 1.00 & \\
\hline $71-80$ & 1 & 79.00 & 0 & \\
\hline
\end{tabular}

(FCV-19: Fear of Covid-19; NS: Not significant)

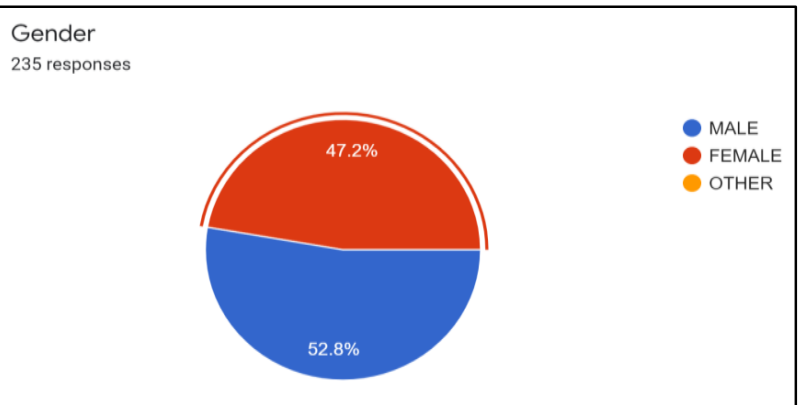

Fig. 1:

Marital status

235 responses

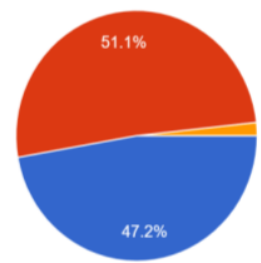

Fig. 2:

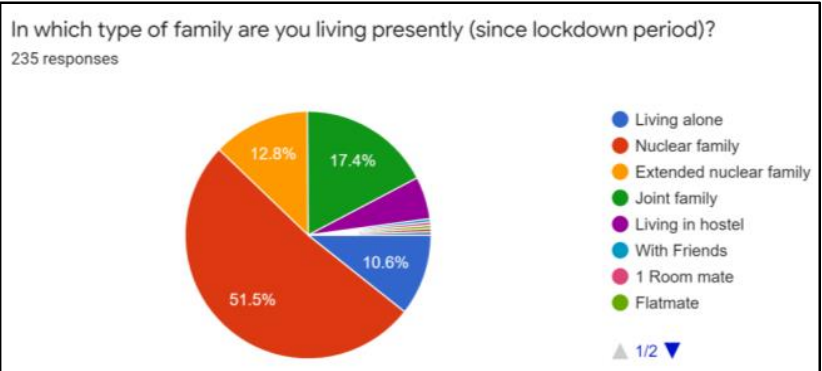

Fig. 3:

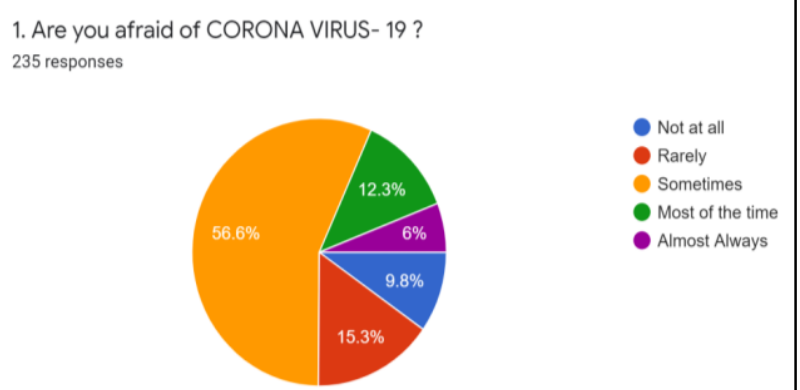

Fig. 4:

2.Does it makes you uncomfortable to think about CORONA VIRUS-19? 235 responses

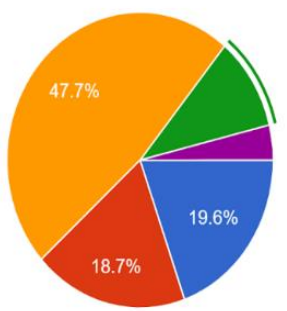

Not at all

Rarely

Sometimes

Most of the time

Almost Always

\section{Fig. 5:}

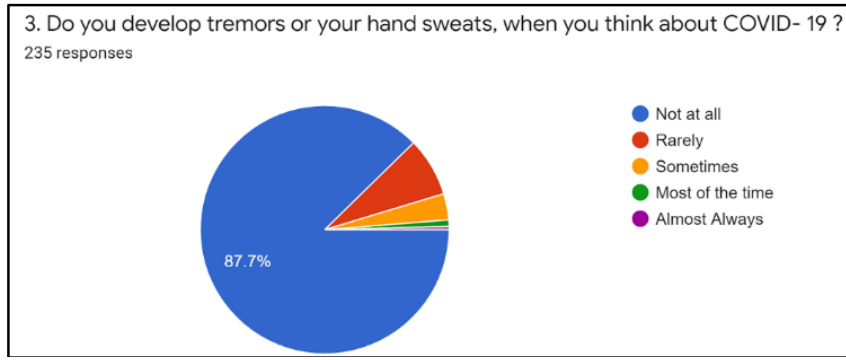

Fig. 6: 


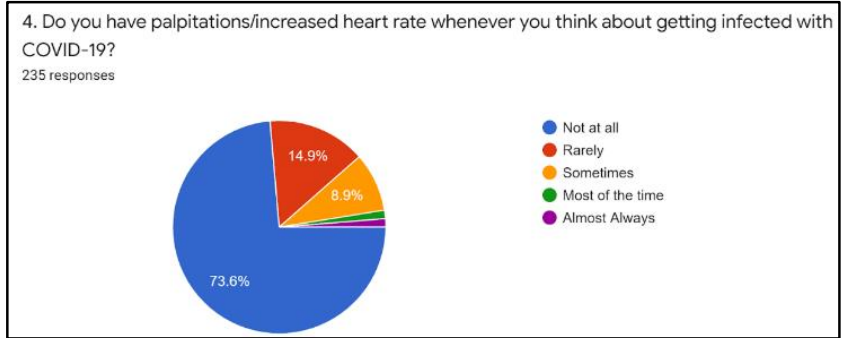

Fig. 7:

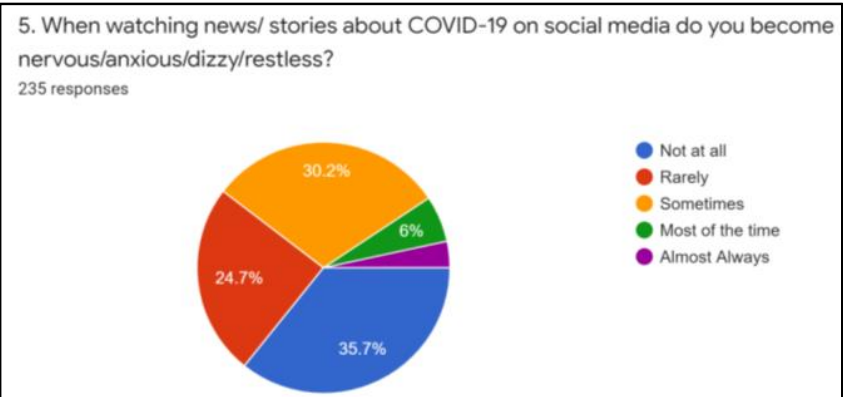

Fig. 8:

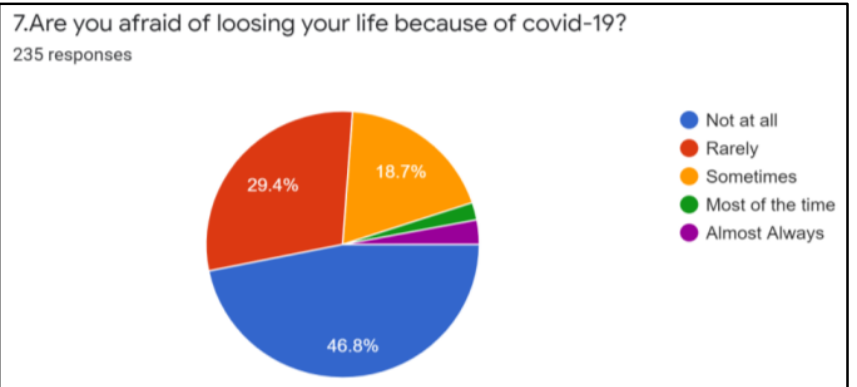

Fig. 9:

\section{Limitations}

1. This study was limited to people who used smart phones, mobile applications, computers and other relevant electronic gadgets.

2. Participants who knew English language could only participate.

3. Participants were restricted to the state of Telangana.

4. Participants were not required to specify area of residence. Hence association between fear of COVID19 in urban vs rural population could not be assessed.

5. The survey was conducted over a short period of time.

\section{Conclusion}

The present survey suggests that there was fear of the novel Corona virus among general population of Telangana. Maladaptive levels of fear about Covid-19, has a huge impact on various aspects of daily life and can cause an emotional toll. Getting help from mental health care experts when needed, can ensure the psychological well-being of individual and society. The results would also help the policy makers in designing appropriate campaigns. It would also help if our medical colleagues could spread awareness about the disease so as to allay the fears, remove stigma and promote preventive measures.

\section{Conflict of Interest}

The author(s) declared no potential conflicts of interest with respect to the research, authorship, and /or publication of this article.

\section{Source of Funding}

None.

\section{Acknowledgment}

We are thankful to all the respondents for participating in this study, taking out their valuable time. We are thankful to those for their cooperation in the conduct of this survey.

\section{References}

1. Holshue ML, DeBolt C, Lindquist S, Lofy KH, Wiesman J, Bruce H, et al. First Case of 2019 Novel Coronavirus in the United States. New Engl J Med. 2020;382(10):929-36.

2. WHO https://www.who.int/csr/don/05-january-2020pneumonia-of-unkown-cause-china/en/

3. Guidelines on the measures to be taken by Ministries/ Departments of Government of India, State/ Union Territory Governments and State/ Union Territory Authorities for containment of COVID-19 epidemic in the country covid19.india.gov.in (dated 24/3/2020)

4. Minding our minds during the COVID-19- MoHFW. www.mohfw.gov.in>pdfPDFWebresultsMindingourmindsduri ngtheCOVID-19-MoHFW (Viewed on 10-july-2020)

5. Guan. Clinical course and risk factors for mortality of adult inpatients with COVID-19 in Wuhan, China: a retrospective cohort study. Lancet. 2020;395:1054-62.

6. Centers for disease control and prevention, Corona virus disease 2019, Reducing stigma (viewed on 14/6/2020) https://www.cdc.gov/coronavirus/2019-ncov/daily-lifecoping/reducing-stigma.html

7. Mhango M, Dzobo M, Chitungo I, Dzinamarira T. COVID-19 risk factors among health workers: a rapid review. Saf Health Work. 2020;11(3):262-5.

8. COVID-19 disrupting mental health services in most countries WHO survey http://www.who.int/news/item/05-10-2020covid-19-disrupting-mental-health- services-in-most-countrieswho-survey

9. Ahorsu DK, Lin CY, Imani V, Saffari M, Griffiths MD, Pakpour AH. The Fear of COVID-19 Scale: Development and Initial Validation. Int J Ment Health Addict. 2020;27:1-9.

10. Arora A, Jha AK, Alat P, Das SS. Understanding coronaphobia. Asian J Psychiatr. 2020;54:102384.

11. Gopalan HS, Misra A. COVID-19 pandemic and challenges for socio-economic issues, healthcare and National Health Programs in India. Diabetes Metab Syndr. 2020;14(5):757-9.

12. Lambert H, Gupte J, Fletcher H, Hammond L, Lowe N, Pelling M. COVID-19 as a global challenge: towards an inclusive and sustainable future. Lancet Planetary Health. 2020;4(8):e312-4.

13. Kamath S, Kamath R, Salins P COVID-19 pandemic in India: challenges and silver linings Postgraduate Medical Journal 2020;96:422-3.

14. Brooks SK, Webster RK, Smith LE, Woodland L. The psychological impact of quarantine and how to reduce it: review of evidence. Lancet. 2020;395:912-20.

15. Xiang YT, Yang Y, Li W, Zhang L, Zhang Q, Cheung T, Ng $\mathrm{CH}$. Timely mental health care for the 2019 novel coronavirus outbreak is urgently needed. Lancet Psychiatry. 2020;7:228-9. 
16. Holmes EA, O'Connor R, Perry VH, Tracey I, Wessely S, Arseneault L, et al. Multidisciplinary research priorities for the COVID-19 pandemic: a call for action for mental health science. Lancet. 2020;7(6):547-60.

17. $\mathrm{Li} \mathrm{Z}, \mathrm{Ge} \mathrm{J}, \mathrm{M} \mathrm{Y}$. Vicarious traumatization in the general public, members, and non-members of medical teams aiding in COVID-19 control. Brain Behav Immun. 2020;88:916-9.

18. Tandon R. COVID-19 and mental health: preserving humanity, maintaining sanity, and promoting health. Asian $J$ Psychiatr. 2020;51. doi: 10.1016/j.ajp.2020.102256.

19. Charlton E. World Economic Forum; 2020. How COVID-19 Has Changed What We Search for Online.

20. Roy D, Tripathy S, Kar S, Sharma N, Verma SK, Kaushal V. Study of knowledge, attitude, anxiety \& perceived mental healthcare need in Indian population during COVID-19 pandemic. Asian J Psychiatry. 2020;51:102083. https://doi.org/10.1016/j.ajp.2020.102083

21. Asmundson GJG, Taylor S. Coronaphobia: Fear and the 2019nCoV outbreak. J Anxiety Disord. 2020;70. doi: $10.1016 /$ j.janxdis.2020.102196

How to cite this article: Shadma Siddiquie S, Ali M, Ali KMZ, Atif KSA, Nasirabadi MZ. Fear of COVID-19: A cross-sectional study among general population in Telangana during lockdown. Telangana $J$ Psychiatry. 2020;6(2):170-175. 